\title{
Article
}

\section{Evaluation of a simplified approach in food safety management systems in the retail sector: A case study of butcheries in Flanders, Belgium and Lancashire, UK}

De Boeck, E, Jacxsens, L., Kurban, S. and Wallace, Carol Anne Available at http://clok.uclan.ac.uk/29916/

De Boeck, E, Jacxsens, L., Kurban, S. and Wallace, Carol Anne ORCID: 00000002-1402-2134 (2020) Evaluation of a simplified approach in food safety management systems in the retail sector: A case study of butcheries in Flanders, Belgium and Lancashire, UK. Food Control, 108 . p. 106844. ISSN 0956-7135

It is advisable to refer to the publisher's version if you intend to cite from the work. http://dx.doi.org/10.1016/j.foodcont.2019.106844

For more information about UCLan's research in this area go to http://www.uclan.ac.uk/researchgroups/ and search for <name of research Group>.

For information about Research generally at UCLan please go to http://www.uclan.ac.uk/research/

All outputs in CLoK are protected by Intellectual Property Rights law, including Copyright law. Copyright, IPR and Moral Rights for the works on this site are retained by the individual authors and/or other copyright owners. Terms and conditions for use of this material are defined in the policies page. 


\section{Evaluation of a simplified approach in food safety management systems in the retail sector: A case study of butcheries in Flanders, Belgium and Lancashire, UK}

De Boeck, E, Jacxsens, L, Kurban, S and Wallace, Carol Anne Available at http://clok.uclan.ac.uk/29916/

De Boeck, E, Jacxsens, L, Kurban, S and Wallace, Carol Anne ORCID: 0000-0002-1402-2134 (2019) Evaluation of a simplified approach in food safety management systems in the retail sector: A case study of butcheries in Flanders, Belgium and Lancashire, UK. Food Control, 108 . p. 106844 . ISSN 09567135

It is advisable to refer to the publisher's version if you intend to cite from the work. http://dx.doi.org/10.1016/j.foodcont.2019.106844

For more information about UCLan's research in this area go to http://www.uclan.ac.uk/researchgroups/ and search for <name of research Group>.

For information about Research generally at UCLan please go to http://www.uclan.ac.uk/research/

All outputs in CLoK are protected by Intellectual Property Rights law, including Copyright law. Copyright, IPR and Moral Rights for the works on this site are retained by the individual authors and/or other copyright owners. Terms and conditions for use of this material are defined in the http://clok.uclan.ac.uk/policies/ 






1

2 3

Title: EVALUTION OF_A SIMPLIFIED APPROACH IN FOOD SAFETY MANAGEMENT SYSTEMS IN THE RETAIL SECTOR: A CASE STUDY OF BUTCHERIES IN FLANDERS, BELGIUM AND LANCASHIRE, UK

\author{
De Boeck E. ${ }^{1}$, Jacxsens L. ${ }^{1 *}$, Kurban, S. ${ }^{1}$, Wallace, C.A. ${ }^{2}$
}

${ }^{1}$ Department of Food Technology, Safety and Health, Faculty of Bio-Science Engineering, Ghent University, Coupure Links 653, 9000 Ghent, Belgium

${ }^{2}$ School of Sport and Wellbeing, University of Central Lancashire, Preston, Lancashire, PR1 2HE, UK *: corresponding author, +32-(0)9 26460 85, liesbeth.jacxsens@ugent.be

\title{
Abstract
}

The EFSA BIOHAZ panel published a scientific opinion proposing a new approach in food safety management, adapted to the needs of small retail businesses such as grocery, butcher, bakery, fishmonger and ice cream shops. The opinion is aiming at a more hands-on development and maintenance of their food safety management system, based on prerequisite programs and HACCP. hazard analysis critical control point-principles(EFSA_BIOHAZ, 2017).. In this paper, the added value of the EFSA opinion is evaluated by comparing requirements with existing legislation and applied guidelines relevant for butchers, and to assess perceptions about introduced changes by this opinion for small independent butcheries in Flanders, Belgium and in North-West England, UK as a case study. Results show that the conditions for flexibilities, as stated in the EFSA opinion, could lead to difficulties in interpretation among Member States. Also, the hazard analysis approach applied in the two main UK guides to good practice appeared to be similar to the simplified approach proposed by EFSA. For Belgium, the main difference is that in the Belgian guide to good practice hazards are ranked and ECPscritical control points are identified for the preparation and selling of fresh meat, minced meat and meat preparations. The specification of PRPsprerequisite programs and related activities in the EFSA opinion can be an important step towards harmonization among EU Member States. The new approach removes hazard ranking and, as such, no critical control points are identified. Instead, thirteen prerequisite programs are linked to monitoring activities, record keeping and corrective actions. The EFSA opinion will advance the development and maintenance of food safety management systems present in butcher shops in a positive way, certainly for the EC Member States, in which the flexibilities for these retail establishments were not appropriately or correctly worked out or interpreted. However, the conditions for allowance of flexibilities are more generally described in the EFSA opinion and these do not completely overlap with the scope at national level (e.g. size, nature and activities of the retail organisations). This could lead to difficulties in interpretation of application of flexibility and may lead to confusion amongst Member States. Assessing the perceptions of 10ten UK and 10ten Belgian butchers revealed that It can be stated that 
the hazard analysis approach and the thirteen prerequisite requirements proposed by EFSA, are generally positively experienced by the butchers. However, the introduction of the proposal 'Monthly microbiological tests' to verify cleaning and disinfection activities is rejected by all the Belgian butchers and by the majority of the UK butchers. This proposal will not ease their job and the necessity of these tests should be reconsidered.

Key words: food safety management system; HACCP plan; butchery; EFSA opinion; hazard analysis

\section{Introduction}

All food companies have to ensure the safety and hygienic status of their food products by the development, implementation and maintenance of a tailored food safety management system (FSMS). However, as stated in the Codex Alimentarius 'General Principles of Food Hygiene', certain flexibility is possible for smaller food companies in order to ease the burden of administration and perceived difficulties in implementation of their FSMS based on prerequisite programs (PRPs) (which includes good hygiene practices (GHP) and good manufacturing practices (GMP) among other good practices) and procedures based on Hazard Analysis Critical Control Point (HACCP) principles (CAC, 2003; EC., 2016). In the European hygiene regulation, the nature and size of the business are defined as the two main criteria making a food business operator eligible for flexibilities, and these are further specified at national level by the Member States (EC., 2004a). So the objective of the introduction of the concept 'flexibility' is actually 'to seek for proportionality of control measures by adaptation to the nature and size of the business' (EC., 2016). The European hygiene legislation also encourages the development and use of guides to good practice to help food business operators to control hazards and demonstrate compliance (EC., 2004a). Many of such guides have already been developed and assessed by national competent authorities for several food sectors. These are mostly dealing with good practices and pre-requisite programs but can also cover some or all HACCPbased principles (EC., 2017; FASFC, 2017). For example, in the case of butcher shops, both Belgian and UK butchers can appeal to such national guides.

Next to these guides, in UK the Food Safety Authority provides 'fact sheets', easy and visual representations of food safety and hygiene procedures (e.g. hand washing) and other information packs to help small businesses with their food safety management procedures and hygiene regulations, via the well-known "Safer Food Better Business" program (FSA, 2019). Similarly, in Belgium the Federal Agency for Safety of the Food Chain (FASFC), published 'quick start fiches' for business-to-consumer (B2C) businesses (FASFC, 2018).

In an attempt to facilitate and harmonize the implementation of EU requirements on PRPs and HACCP principles and clarify flexibilities in this matter, the European Commission published a 
'Commission Notice on the implementation of procedures based on the HACCP principles, and facilitation of the implementation of HACCP principles in certain food businesses' (EC., 2016). Several practical solutions focusing on the simplification of some system areas such as flow diagrams, hazard analysis, documented procedures and records are described. The document also states that for certain categories of food businesses with identical, standardised and limited handling of food (e.g. butcher shops), it may be possible to pre-determine hazards that need to be controlled. Guidance on such hazards and on the control thereof can be addressed in a generic HACCP guide (EC., 2016). In small non-industrial establishments, HACCP should be used as a means of managing food safety, highlighting the importance of critical control points (CCPs) and monitoring operations, rather than strictly complying with the seven principles defined for the food industry (Panisello \& Quantick, 2001). In certain cases, a hazard analysis may demonstrate that no significant hazard has been identified and therefore there is no need for CCPs. In this case all food hazards can be controlled by the implementation of the PRPs (EC., 2016). For example, distributors of non-perishable food products (e.g. for food donation) may not need any CCPs to safeguard food safety and hygiene (De Boeck, Jacxsens, Goubert, \& Uyttendaele, 2017).

However, the question remains whether this flexibility may pose a greater potential for failures in food safety and hygiene rules and at the end foodborne disease, especially when working with quite risky products from a microbiological perspective, such as raw meat in a butcher shop (De Boeck, Jacxsens, Bollaerts, Uyttendaele, \& Vlerick, 2016).

The report from the Commission (FVO, 2015) on the experience gained in Europe from the application of the hygiene Regulations (EC) 852/2004 (EC., 2004a), (EC) 853/2004 (EC., 2004b) and (EC) 854/2004 (EC., 2004c), identified certain difficulties with their implementation particularly in small food businesses in most Member States. An important issue raised, is dealing with the concept of 'flexibility' as described in Regulation (EC) 852/2004 (EC., 2004a). Managing flexibilities in FSMS is a national affair, as prescribed in EU Regulation (EC) 852/2004, 'nature' and 'size' should be defined by authorities at national level. However, according to the FVO report (FVO, 2015), Member States are experiencing difficulties to deal with these concepts. Also semantic structures in these legislative texts (e.g. Regulation 852/2004) such as "if applicable" or "if necessary" are difficult to interpret (BIO_by_Deloitte, 2014; De Boeck et al., 2017). This lack of clarity, leads to fragmentation of Member States' food safety policies and the risk that Member States hold different standards with respect to food safety and hygiene. For example, in Poland, EU Regulation (EC) 852/2004 is interpreted very rigidly, making it nearly impossible for food banks to distribute food donations, whereas in Belgium provisions are foreseen (e.g. freezing food at the end of shelf life for food donation) enabling these activities (BIO_by_Deloitte, 2014). So in some cases, flexibility is not permitted at all or is only permitted by the control authority in cases where an officially adopted guide is available (e.g. self- 
checking guides approved by the Belgian food safety authority), resulting in small businesses being required to maintain unnecessary levels of documentation. As such, the Member States highlighted in the FVO report the need for more practical guidance, including examples, on flexibility which would address at least the following: (i) what constitutes flexibility, (ii) where flexibility is permissible, and (iii) under what conditions flexibility may be granted. The latter would need to provide some clarity on the required level of documentation (FVO, 2015).

In this context, the BIOHAZ panel of EFSA prepared a scientific opinion proposing a new approach which is adapted to specific types of retailers' needs and which would facilitate the development and maintenance of the FSMS (EFSA_BIOHAZ, 2017). Addressing first the issue of understanding the concept of 'flexibilities', in this EFSA opinion it is stated that flexibility in FSMS means that for each food business at least compliance with relevant PRPs is required and that a hazards analysis must be carried out using a risk-based approach to determine the necessity to establish CCPs (EFSA_BIOHAZ, 2017). This document also introduces changes in the process of hazard analysis in comparison to the Codex approach: for example, the grouping of the hazards to reduce detailed information, the elimination of hazard ranking and the need for CCPs by controlling all the hazards with PRPs. For five types of small retail businesses: grocery, butcher, bakery, fishmonger and ice cream shops, a FSMStable is developed which may replace the current HACCP-plan. Moreover, a table of PRPs is proposed, accompanied with control and monitoring activities, record keeping requirements, and corrective actions. This means that businesses falling within these specific retailer groups (grocery, butcher, bakery, fishmonger, ice cream shop) can adopt this simplified process and associated control and monitoring requirements without the need to perform their own hazard analysis or HACCP study; however, care must be taken to ensure that the food handling processes used by the businesses are indeed in line with those considered within the EFSA scientific opinion (EFSA, 2017). Latronico et al. (2017) states that "the EFSA opinion takes into consideration a detailed analysis of constraints in implementing FSMS and provides guidelines in a user-friendly way". However, no evaluation of this EFSA opinion is available in scientific literature. As such the aim of this research was to evaluate the added value of this EFSA opinion compared to existing legislation and guidelines relevant for UK and Belgian butchers (objective 1), and to assess perceptions about introduced changes by this opinion for small independent butcheries in Flanders, Belgium and butcheries in North-West England, UK as a case study (objective 2). For the first objective, a document review was performed in which conditions for flexibilities, hazard analysis approach and PRP requirements are compared between the EFSA opinion and relevant documents (e.g. guides to good practice). For the second objective face-to-face interviews were performed to investigate the opinion of the butchers about the introduced changes. 


\subsection{Objective 1: Method for document review}

\subsubsection{Selection of documents}

Relevant documents were selected based on searches in database of EURLEX, websites of national sector organizations and food safety authorities, and discussions with experts in European an national legislation regarding food safety and hygiene from both UK and Belgium (belonging to Department Food Technology, Safety and Health, Ghent University, Belgium and School of Sport and Wellbeing, University of Central Lancashire, UK). Following documents were considered relevant: the EFSA opinion under study (EFSA_and_ECDC, 2017), Commission Notice on the implementation of procedures based on the HACCP principles, and facilitation of the implementation of HACCP principles in certain food businesses (EC., 2016) and the national guides to good practice. With regard to these national guides, in Belgium, a self-check guide is freely available on the official website of the Belgian food safety authority (FASFC, 2015). The Belgian self-checking guide contains informative instructions and addresses biological, chemical and physical risks. It provides advice on purchasing food, the use of recognised food contact materials, proper organisation of food in fridges, cooking and distribution of food. In Belgium, these national agreed guides are used as auditing reference to validate the organization's FSMS. In the UK, several guides are available. Firstly, a basic hygiene guideline document, named 'Food Hygiene, a guide for businesses' (FSA, 2013), which is a general document for all catering and retail establishments. 'Safe Food Handling for Butchers' (FSA, 2012) is a guideline for he butchers and is developed by a consultative group in Northern Ireland. 'ButcherSafe' (Food_Standards_Scotland, 2013) is another guide originating from Scotland. These are both provided via the Food Standards Agency (FSA) website. In addition, another guidance is provided by 'Meat Training Council': 'HACCP review and guidance manual for retail butchers' (MTC, 2016). However, as this guide is provided against payment and is a considerable cost for small butcher shops, the latter guidance document will not be included further in this research. It should also be noted that, in contrast to the situation in Belgium, no certification against these guides is possible, and connection of UK butcher shops to an association of butcher shops is less common. The guides included in this study, legal documents and the EFSA opinion are freely available online.

\subsubsection{Comparison of the reference documents}

For the comparison of the included reference documents, tables were made describing the requirements for each section of the documents and this was discussed by the experts. For the comparison of the conditions to be eligible for flexibilities, conditions described in the EFSA opinion (EFSA_BIOHAZ, 2017) (to be eligible for using the proposed simplified hazard analysis proposed in this document) were compared with the self-checking guide of Belgium (FASFC, 2015) and two guides 
173 from the UK (Food_Standards_Scotland, 2013; FSA, 2012) (Results: see 3.1 .1 and Table 1).

174 Comparison of the hazard analysis approach was first investigated at European level. The approach described in the EFSA opinion (both proposed simplified approach and classical approach as described in this document) was compared with the approach described in the Commission Notice on FSMS (EC., 2016) (both 'classical' approach and approach applicable to companies eligible for flexibilities) (Results: see 3.1.2 and Table 2). Secondly, also the approaches described in the national guides (Belgium and UK) were investigated (Results: see 3.1.3 and Table 2). Prerequisite requirements were compared between the EFSA opinion and the national guides (Belgium and UK) (Results: see 3.1.4 and Table 2).

\subsection{Objective 2: Method for assessment of perception of butchers}

184

185

186

187

\subsubsection{Selection and characteristics of butchers}

For the sample of the butchers to be interviewed, micro scale independent butcher shops which can profit from the national flexibilities were targeted for this research. Affiliated butcher shops, being affiliates of a large scale centrally coordinated meat distribution company were excluded. Also, butchers not meeting the conditions for national flexibilities were considered out of the scope. Only butcher shops meeting the conditions were interviewed. Participation was completely voluntary and willingness to participate was respected. This was a convenience sample, as butcher shops in the neighbourhood were contacted via acquaintances in Antwerp, Flanders and via contacting those within a geographical area of Preston, UK. All included Belgian butchers $(n=10)$ used the national guide to good practice (FASFC, 2015). In the UK, where more guides are available, two of the interviewed butchers used the guide 'Safe Food Handlings for Butchers' (FSA, 2012), seven used 'ButcherSafe' (Food_Standards_Scotland, 2013) and one of them used 'HACCP review and guidance manual for retail butchers' (MTC, 2016).

\subsubsection{Design questionnaire}

The questionnaire was developed by the same group of experts performing the document review (see section 2.1). As current practices with respect to HACCP and prerequisite programs' implementation might be different for Belgium and the UK, two separate questionnaires were developed based on the document review. First part of the questionnaire consists of general questions about the organisation of the butcher shop. The second part was based on the document review. An overview was made of changes (compared to national guides) in PRP and HACCP requirements proposed in the EFSA opinion, and these were then included in the questionnaire via questions comparing changes proposed by EFSA to the butchers' current practice (e.g. Is a registration form filled out for each monitoring of temperature of the cold storage room?) and 
questions asking for the opinion of the butchers towards the proposed changes (e.g. How do you experience the proposal of EFSA to execute monthly microbiological analysis for monitoring of cleaning and disinfection?). The survey contained mainly open questions. The questionnaire for the Belgian butchers was in Dutch and consists of 32 questions. The questionnaire of the UK was in English and consists of 48 questions (see Appendix A for full questionnaires).

\subsubsection{Face-to-face interviews}

Face-to-face interviews with the responsible manager/supervisor of each butchery in both Belgium and the UK were performed. At the outset, the responsible manager/supervisor of the butcher shop received an announcement letter. In this letter, the butchers were fully informed about the purpose of the study. The voluntary nature of their participation and how the data would be anonymised and used was explained. Each interview took approximately 30-45 minutes and was performed by the same interviewer both in Flanders and in UK. Before use, a validation of the questionnaires was executed. A preliminary survey was used by the interviewer to conduct the interview with one extra Belgian and UK butcher. Also terminology and formulation of the questions was discussed. Hygiene conditions in the butcheries were not assessed during the visits for the interviews, as this was not within the scope of this study.

\subsubsection{Data processing}

The responses of the interviews were registered. For the questions related to how proposed changes were experienced by the butcher, a categorization was executed. The responses were categorized as positive, neutral or negative (towards each change proposed by EFSA) by the interviewer, as the latter could also capture underlying sentiments during the conversations with the butchers. The general questions and questions about current practices were not further processed, but were used in case extra information was needed to explain positive, negative or neutral appraisal of proposed changes. The results were presented in graphs for the Belgian and UK butchers for each PRP/hazard analysis step introducing changes proposed by EFSA (Results: see 3.2.1, 3.2.2, Table 3 and Figure 1).

\section{Results and discussion}

\subsection{Objective 1: Results for document review: Comparison of conditions for flexibility,} hazard analysis approach and PRP requirements

\subsubsection{Conditions for flexibility}

Results of the document review for the comparison of conditions for flexibility are given in Table 1. The conditions in Belgium and the UK are both expressed as the extent of delivery to other businesses/organisations (B2B). Butcher shops supplying to other organisations are only eligible in case of limited distance and percentage of sales. Small butcher shops, delivering only to the final 
consumer (B2C), are in any case eligible for flexibilities. The scope in the EFSA opinion (EFSA_BIOHAZ, 2017)) is more general and does not completely overlap with the scope on national level. The EFSA opinion defines the size and the nature of the business instead of the limitation for B2B deliveries. The EFSA opinion refers to small businesses which serve to local customers but does not specify the distance. This could be because distances are not comparable between Member States of different sizes, which would hinder harmonization.

The production of meat products is not in the scope of the EFSA opinion. This means that some butcher shops who currently profit from the flexibilities are not fully eligible for the simplified approach proposed by EFSA. However, purchased meat products from the meat industry, can still be sold in the shop. As such, two possibilities can be deduced: butchers may apply the simplified approach if they are fully eligible, or butchers may only apply the simplified approach to the products concerned. This is not specified in the EFSA opinion and could lead to confusion and different interpretations between the Member States.

It could be stated that this concept of 'flexibility' is generally difficult to interpret, especially by smaller businesses without extensive knowledge related to food safety and hygiene legislation. The Commission Notice gives some clarification on how to interpret 'nature' and 'size' as eligibility criteria (EC., 2016). Nature is related to activity (e.g. processing versus only storage of packaged products) of the business and should be assessed in a risk-based way. With respect to size, the Commission Notice refers to e.g. production volume and throughput.

\subsubsection{Hazard analysis approach: change compared to current European legislation}

The classical hazard analysis approach, the simplified approach proposed by EFSA (EFSA_BIOHAZ, 2017) and the approach described in the Commission Notice on the implementation of FSMS (EC., 2016) are compared (Table 2). For the Commission Notice, the comparison is made for 2 cases: with and without taking into account the flexibilities for small businesses. The differences introduced by EFSA are highlighted in bold.

An important finding is that in the EFSA opinion, the proposed simplified approach, which is intended for small establishments profiting from flexibilities, is compared with the classical approach (corresponding to the hazard analysis approach without taking into account the flexibilities), instead of comparing with the hazard analysis approach taking into account the flexibilities (as described in the Commission Notice (EC., 2016)). Comparing the simplified approach with the hazard analysis approach without the flexibilities introduces changes in each step, promising changes for improvement. For the classical approach without the flexibilities, the most important change introduced by the EFSA opinion, is the fact that no detailed description and knowledge is required for the hazard identification and the removal of the hazard ranking. If flexibilities already proposed in 
the Commission Notice are taken into account, there is only one major change, i.e. the removal of the hazard ranking.

\subsubsection{Hazard analysis approach: changes compared to national guides to good practice}

In Table 2, the EFSA opinion (EFSA_BIOHAZ, 2017) is further compared with the national guides to good practice for Belgium and UK. In case in these documents, a difference was noticed with the EFSA simplified approach, this was highlighted in bold. For all presented guides, the hazard analysis is pre-developed in the guide and is 'ready-to-use' by the butchers. For the Belgian guide also hazard identification and hazard ranking are premade and flow diagrams and HACCP-plans for each product group are provided. As such, no detailed description and knowledge about the nature of the hazard is necessary from the butchers. This detailed description and knowledge was required in the classical approach (according to the EFSA opinion and Commission Notice). The documentation related to the FSMS in Belgium can be replaced by the guide according to the Ministerial Decree of 2 March 2013 (FASFC, 2013) concerning the flexibilities of the application modalities of self-checking and traceability in some establishments in the food chain. This removal of hazard ranking is a change compared to the classical approach, the approach in the Commission Notice and the Belgian selfchecking guide, but not for the UK guides.

In the two guides of the UK, the current approach is similar to EFSAs proposed approach. UK guides also do not specify the hazards nor include hazard ranking. The guide 'ButcherSafe' identifies the stages. Hazard identification is not based on the stages but on the PRPs. Still, this is not considered a real change introduced by the EFSA opinion. This guide gives a definition for CCPs, but manages all hazards via 'house rules', which can actually be considered as PRPs. For the guide 'Safe Food Handling for Butchers', every hazard is linked to control, monitoring, record keeping and corrective actions, but CCPs are not really specified.

In practice, if the simplified hazard analysis approach would be introduced, the guides would be adjusted. The butcher must then obtain the updated guide to comply with legislation.

To conclude, the new approach removes hazard ranking and, as such, no CCPs are identified. Instead, the 13 PRPs are linked to monitoring activities, record keeping and corrective actions. This is similar to the approach used in UK. As hazard ranking is omitted, all the hazards are identified as critical and the criticality seems to be indicated by the level and frequency of monitoring and record keeping requirements. For the case of Belgium, the simplified approach seems to be more a restructuring of the FSMS without CCPs. This could be due to the fact that in the national self-checking guide, certain preventive measures such as storage temperature of food products and reception of raw materials are, sensu stricto, wrongly indicated as CCPs according to the HACCP-principles of CAC (2003) and EU 
Regulation 852/2004 (EC, 2004a). However, it was a risk management/policy decision to introduce these CCPs, probably because it was deemed inappropriate not to have any CCP in a HACCP plan. As such, the EFSA opinion actually rectifies this mix-up between PRPs and CCPs. This illustrates that we have to pay attention that, although in some cases some flexibility and simplification in the implementation of FSMS is necessary, we do not lose track of the fundamental HACCP-principles behind it.

\subsubsection{Comparison approach to manage prerequisite programs}

The EFSA opinion (EFSA_BIOHAZ, 2017) provides a summary of pre requisite activities including the 12 defined PRPs from the Commission Notice (EC., 2016) and an additional PRP 'product information and consumer awareness'. Furthermore, the activities, monitoring, extent of record keeping and corrective actions are specified for each of the PRPs. As an example, a comparison is made of requirements in the EFSA opinion with the national guides to good practice for PRP 2 'Cleaning and Disinfection' and PRP 11 'Temperature control of storage environment' in Table 3. Table 3 shows that for cleaning and disinfection the EFSA opinion introduces a change with respect to monitoring activities for both UK and Belgian butchers (following the national guides), as EFSA proposes a monthly microbiological check of cleaning and disinfection. With respect to temperature control, mainly the Belgian butchers will be affected, as according to the Belgian guide registration was only necessary in case of non-compliance, whereas the EFSA opinion proposes to keep records for each monitoring. This does not introduce changes for UK butchers.

An additional PRP 'product information and customer awareness' (PRP 13) is proposed in the EFSA opinion (EFSA_BIOHAZ, 2017), which makes the set of PRPs for small scale retail shops more complete. However, the Belgian butchers are already required to inform the consumer written or orally about the conditions of use, storage conditions, shelf life, presence of allergens etc. Moreover, they should keep a written statement in the store stating that allergen information can be requested. In the UK, the information given is limited to allergen and shelf life information. Awareness about the role and responsibility of the consumer in managing food safety is emerging in the last decade (Mensah \& Julien, 2011). Consumer complacency on food hygiene is a major source of food-borne illnesses (Redmond \& Griffith, 2003). Expecting butchers to provide each customer all the required information, might be an impossible task during peak hours. Considering this as a responsibility of butcher might also increase complacency from consumers. Increasing the awareness of the consumer requires effort, but would be an important strategy. Awareness campaigns, posters in the shop illustrating 'proper handling of meat, storage conditions' could be complementary to achieve the goal of this prerequisite (De Boeck et al., 2016). 


\subsection{Objective 2: Results for butchers' perceptions}

\subsubsection{Opinion about changes in simplified hazard analysis approach}

For Belgium, the first two steps of hazard analysis do not induce changes compared to the current requirements as explained earlier (see 3.1). However, the third step 'hazard ranking', is removed in the simplified hazard analysis approach according to the EFSA opinion (EFSA_BIOHAZ, 2017). The opinion of Belgian butchers about this change was asked (see Appendix A). None of the Belgian butchers were against this proposal. Nine butchers of the ten were positive. Generally, they found it would be easier to understand, less technical and less complicated, but they were mostly aware that it would not affect them in their daily routine. In practice, no major changes will occur for the Belgian butchers, due to the fact that the Belgian guide provides a pre-developed ready-to-use HACCP-table. It is sufficient for the small retailers to keep the guide in the butcher shop and to consult it when necessary. This guide replaces also the documentation for procedures based on HACCP principles. Even though, it would not be a big change in practice, a less complex HACCP-table is certainly appreciated by the butchers. For UK butchers, no questions were asked concerning the simplified hazard analysis approach as it does not introduce changes. It is remarkable that the simplified hazard analysis approach proposed by EFSA does not introduce big changes in practice for both UK and Belgium regarding hazard analysis. Most probably because the existing guidelines already simplified the HACCP-principles for them.

\subsubsection{Opinion about changes in prerequisite requirements}

Figure 1 represents web diagrams with the percentage of positive, negative and neutral opinions by the Belgian (right) and UK (left) butchers. Belgian and UK butchers, using different guides, might experience the proposal in governing PRPs differently. As the butchers' opinion is only asked about PRPs which introduce changes compared with the requirements described in the guide, more points are indicated in the web diagram showing the results of the UK butchers' opinion than in the web diagram referring to the Belgian butchers' opinion (Figure 1).

The UK butchers were generally more positive about the introduced changes related to the facilitation of the record keeping requirement. Although this should introduce changes as workload would be expected to decrease, in practice, some of the butchers were already deviating from the prescriptions in the current guide. The proposal by EFSA to check visually cleaning and disinfection each day (Table 3 and PRP 2 (M) in Figure 1) is in both Member States (UK and Belgium) already the case in practice. The UK and Belgian butchers were both aware of the importance of cleaning and disinfection and do the daily check spontaneously although it is not required in the guide. This explains why most butchers (UK: $80 \%$ and Belgium: 100\%) were positive about this change (Figure $1)$. 
Both UK and Belgian butchers perceived some of the changes as neutral. These changes are mostly

377 related to proposals introducing higher frequency of monitoring for the Belgian butchers. The majority (>50\%) of the Belgian butchers were neutral about the proposal of a weekly check of the pests (PRP 3,60\%) and a continuous monitoring of the equipment (PRP 4a, 60\%). They were neutral about the requirement of a monthly visual check of the infrastructure (PRP 1,70\%), which is now recommended but not mandatory. Respondents with neutral responses claimed that this has become a routine. The UK butchers were mainly neutral about proposals introducing record keeping by exception. This is the case for PRP 1 'Infrastructure: building and equipment' (60\%), PRP 2 'Cleaning and disinfection' (50\%) and PRP 5 'physical and chemical contamination from the production environment' $(60 \%)$. The same reason holds as for the Belgian butchers with neutral responses: they did not consider it a big effort to fill out the check list, as this is considered a routine. Attention should be paid to the requirements experienced negatively by the butchers. In both cases the introduction of the requirement of 'monthly microbiological tests' to check cleaning and disinfection (Table 3 and PRP 2 on Figure 1 ) is rejected by all the Belgian butchers ( $n=10)$ and by $60 \%$ of the UK butchers. The issue here is mostly cost of these analyses. Moreover, lack of expertise and knowledge in food safety and hygiene could hinder correct interpretation of lab results and putting in place suitable corrective actions. Taylor (2001) states that small businesses often consider food safety as a public good and that associated costs should be paid by government or other agencies. As these challenges (such as lack of expertise) also hold for other types of small food establishments, further research is advised to investigate perceptions experienced by these other types of small food establishments within the scope of the EFSA opinions. Still, for other changes in prerequisite requirements most UK butchers $(<50 \%)$ did not negatively experience the proposal by EFSA. So, it can be concluded that the UK butchers are in general not negative about the proposals of EFSA concerning the PRPs. On the contrary, most Belgian butchers $(>50 \%)$ were negative about four additional changes, i.e. the record keeping requirements for PRP 1 (R) (70\%), periodic (daily/weekly) check of the calibration PRP 4b (M) (70\%), 'record keeping only when there is remedial work required for physical and chemical contamination of production environment' for PRP 5 (R) (70\%) and the 'record keeping requirement for all the controls of the temperature' PRP 11 (R) (60\% in Figure 1 and see also Table 3). For these prerequisites bigger changes and higher workloads are introduced for Belgian butchers and less or none for UK butchers. For PRP 5, currently, measures to prevent physical and chemical contamination are extensively described in the Belgian guide, without the requirement of record keeping. The supervisor should control the compliance of these requirements. In practice, all the butchers are doing this unconsciously. This PRP also overlaps with other PRPs like pest control (PRP 3), cleaning and disinfection (PRP2) etc. According to the Belgian butchers, this would be time-consuming and unnecessary. On the contrary, for UK, the butcher (supervisor) should 
tick the box after control and register the corrective action taken. EFSA proposes to write down only the corrective actions taken. That explains why the majority $(n=6)$ is neutral about the change, as they were already registering this. Four of them are more positive stating that the change would make work easier. With regard to PRP 11, the majority of Belgian butchers ( $n=6)$ only record nonconformities in temperature, which is required by the current butcher guide. The other four butchers have an automated monitoring with alarm and continuous record keeping. For the latter butchers, there is no extra burden due to the proposal of recording all temperature checks, but for the other 6 butchers this is negatively perceived as this would be very time-consuming. For UK butchers, again, no changes are introduced with their current practice as this is already required.

\section{Limitations of the research and further developments}

This research only focused on butcher shops, whereas the EFSA opinion (EFSA_BIOHAZ, 2017) concerns five types of small retail businesses (butcher, grocery, bakery, fish and ice cream shop) established in the European Union. The other establishments could be affected differently or could have different opinions about the proposals, which is not taken into account in this research. Also, the opinion concerns all the Member States whereas in this research only Belgium and the UK are considered. National (food safety) culture differences might have an impact on perceptions concerning the proposals raised in the EFSA opinion. Moreover, food business operators in Member States where no such guides to good practice exist, might respond differently than food business operators from Member States providing national guides. Further research including other Member States, could provide insights in these national differences. Also, the document comparison was only performed for two freely available guides in UK (Safe Food Handlings for Butchers' (FSA, 2012) and 'ButcherSafe' (Food_Standards_Scotland, 2013)), whereas in UK more guides are available (against payment).

Moreover, because of the limited sample size of ten butchers in each country and the voluntary participation of the butchers, this sample is not representative for all the butchers in Belgium and the UK. However, the low sample does allow more in depth-interviews. During the face-to-face interview, further explanation of the proposals was possible, which gives a high input quality in contrast to a survey with higher response rate.

It should be noted that, in 2018, a second EFSA scientific opinion was published: Hazard analysis approaches for certain small retail establishments and food donations: second scientific opinion (EFSA_BIOHAZ, 2018). The aim of this opinion is to develop a similar approach for other small retail establishment including retail distribution centres, supermarkets, restaurants and food donation. In a lot of these retail establishments limited resources are available and staff turnover is high, posing challenges towards building and keeping knowledge and expertise regarding food safety and hygiene 
(De Boeck et al., 2017). Especially for food donation at retail level novel food safety challenges are presented, as many actors are involved in the food donation/acceptation chain and as the donated food may be near to the end of its shelf life (EFSA_BIOHAZ, 2018). This second scientific opinion was not included in this research.

\section{Conclusion}

In this research the added value of the EFSA opinion (EFSA_BIOHAZ, 2017) is evaluated. With respect to objective 1 (document review), it can be stated that the formulation of conditions for flexibilities in the EFSA opinion could lead to difficulties in interpretation among different Member States. Looking at the hazard analysis approach, it can be concluded that for the case of the UK, the hazard analysis approach of the two concerned UK guides to good practice is similar to the simplified approach proposed by EFSA, as the general and specific hazards are also merged and hazards are not ranked. In contrast, the Belgian guide does rank the hazards and identifies CCPs for the preparation and selling of fresh meat, minced meat and meat preparations. With regard to documentation and requirements related to PRPs, it can be stated that by specifying PRPs and related activities on European level, the first steps towards harmonization of the verification requirements related to the PRPs in establishments profiting from flexibilities have been taken.

With respect to objective 2 regarding the perceptions of 10 butchers from Belgium and 10 butchers from UKWith respect to objective 2 regarding the perceptions of 10 butchers from Belgium and 10 butchers from UK, the hazard analysis approach and the thirteen PRPs proposed by EFSA, are generally positively experienced by the butchers. However, it is recommended in this research to reconsider the few proposals negatively experienced by the butchers (e.g. monthly microbiological analysis). Nevertheless, simplifying the requirements is only possible to a certain point as flexibility may not pose risks to food safety.

\section{REFERENCES}

CAC. (2003). General Principles of Food Hygiene, C.A. Commission, CAC/RCP 1-1969. http://www.fao.org/fao-who-codexalimentarius/codex-texts/all-standards/en/, last accessed on the 22nd of June 2019.

De Boeck, E., Jacxsens, L., Bollaerts, M., Uyttendaele, M., \& Vlerick, P. (2016). Interplay between food safety climate, food safety management system and microbiological hygiene in farm butcheries and affiliated butcher shops. Food Control, 65, 78-91.

De Boeck, E., Jacxsens, L., Goubert, H., \& Uyttendaele, M. (2017). Ensuring food safety in food donations: Case study of the Belgian donation/acceptation chain. Food Research International, 100, 137-149. Retrieved from <Go to ISI >://WOS:000413128800015. doi:10.1016/j.foodres.2017.08.046 
EC. (2004a). Regulation No 852/2004 of the European Parliament and of the Council of 29 April 2004 on the hygiene of foodstuffs. Official Journal of the European Union, L139, 1-54.

EC. (2004b). Regulation No 853/2004 of the European Parliament and of the Council of 29 April 2004 laying down specific hygiene rules for food of animal origin. Official Journal of the European Union, L226, 22-82.

EC. (2004c). Regulation No 854/2004 laying down speific rules for the organisation of official controls on products of animal origin intended for human consumption. Official Journal of the European Union, L226, 83-127.

EC. (2016). Commission Notice on the implementation of food safety management systems covering prerequisite programs (PRPs) and procedures based on the HACCP principles, including the facilitation/flexibility of the implementation in certain food businesses. Official Journal of the European Union, C278/271-C278/232.

EC. (2017). Guides to good practice, https://ec.europa.eu/food/safety/animal-feed/feedhygiene/guides-good-practice en, accessed on the 15th of June 2017.

EFSA_and_ECDC. (2017). The European Union summary report on trends and sources of zoonoses, zoonotic agents and food-borne outbreaks in2016. EFSA Journal, 15(12), 5077.

EFSA_BIOHAZ. (2017). Scientific Opinion: Hazard analysis approaches for certain small retail establishments in view of the application of their food safety management systems. EFSA Journal, 15 (3), 4697. doi:10.2903/j.efsa.2017.4697

EFSA_BIOHAZ. (2018). Hazard analysis approaches for certain small retail establishments and food donations: second scientific opinion. EFSA Journal, 16(11), 5432.

FASFC. (2013). Ministerial Decree 22/03/2013: Ministerieel besluit betreffende de versoepeling van de toepassingsmodaliteiten van de autocontrole en de traceerbaarheid in sommige inrichtingen in de voedselketen. Belgisch Staatsblad 05-04-2013, 2013018181, 21351-21354.

FASFC. (2015). Guide for autocontrol in the butchery-butcher shop (G-003-Version 2). http://www.favv.be/autocontrole-nl/gidsen/distributie/g003/, accessed on the 5th of July 2017.

FASFC. (2017). Self-checking guides, http://www.favv.be/autocontrole-nl/gidsen/, accessed on the 15th of June 2017.

FASFC. (2018). Quick start fiches. http://www.favv.be/autocontrole-nl/gidsen/qsfiches/default.asp, last accessed on the 3rd of February 2018.

Food_Standards_Scotland. (2013). ButcherSafe, Food Safety Assurance System. http://www.foodstandards.gov.scot/downloads/ButcherSafe Full PDF Manual with FSS logo.pdf, last accessed on the 20th of July 2018: TSO.

FSA. (2012). Safe food handling for butchers. https://acss.food.gov.uk/sites/default/files/butchershaccp.pdf, last accest on the 2nd of August 2018.

FSA. (2013). Food hygiene- a guide for businesses. FSA/1690/0613. https://www.rushmoor.gov.uk/CHttpHandler.ashx?id=15972\&p=0, last accessed on the 1st of August 2018.

FSA. (2019). Safer Food Better Business fact sheets. https://www.food.gov.uk/businessguidance/safer-food-better-business, last accessed on the 3rd of July 2019.

FVO. (2015). Overview Report: Better HACCP implementation. Luxembourg: Publications Office of the European Union. ISBN 978-92-79-43526-3. doi:10.2772/59374. 44 pp.

Latronico, F., Correia, S., Felicio, T. D., Hempen, M., Messens, W., Ortiz-Pelaez, A., . . . Hugas, M. (2017). Challenges and prospects of the European Food Safety Authority biological hazards risk assessments for food safety. Current Opinion in Food Science, 18, 50-55. Retrieved from $<$ Go to $|S|>$ ://WOS:000417079000009. doi:10.1016/j.cofs.2017.10.013

Mensah, L. D., \& Julien, D. (2011). Implementation of food safety management systems in the UK. Food Control, 22, 1216-1225.

MTC. (2016). HACCP review and guidance manual for retail butchers. https://www.foodtraining.org.uk/wp-content/uploads/2016/11/Haccp-Review-andGuidance-MAnual-order-form-V3-5-12-16.pdf, last accessed on the 3rd of August 2018. 
Panisello, P. J., \& Quantick, P. C. (2001). Technical barriers to Hazard Analysis Critical Control Point (HACCP). Food Control, 12(3), 165-173. Retrieved from <Go to ISI>://WOS:000168160200004. doi:10.1016/s0956-7135(00)00035-9

Redmond, E. C., \& Griffith, C. J. (2003). Consumer food handling in the home: A review of food safety studies. Journal of Food Protection, 66(1), 130-161. Retrieved from <Go to |S|>://WOS:000180383000021.

Taylor, E. (2001). HACCP in small companies: benefit or burden? Food Control, 12(4), 217-222. Retrieved from <Go to ISI>://WOS:000168605700005. doi:10.1016/s0956-7135(00)00043-8 
Table 1: Comparison of conditions for flexibilities according to the EFSA opinion (EFSA_BIOHAZ, 2017), the national guide to good practice in Belgium (FASFC, 2015) and the guides in UK (Food_Standards_Scotland, 2013; FSA, 2012)

EFSA a) The small retail establishments (butcher, grocery, bakery, fish and ice cream shops) covered are typically 'micro' business.

b) The size of micro businesses is defined as having less than 10 employees (but in many cases, may have as few as two to three employees), with a turnover or balance sheet total of $€ 2$ million or less.

c) The nature of micro businesses is defined by the qualities they generally share:

They serve local customers; have a limited share of the available market;

are owned by one person, or by a small group of people;

are managed by their owners who deal with all management issues, usually with little other help;

they are independent businesses not parts of, or owned by, larger companies.

e) In the flowchart for butcher shops it can be derived that the production of meat products is out of the scope.

BE a) Delivers only to the final consumer (B2C); or

b) Deliveries limited up to maximum $30 \%$ of the sales within a radius of $80 \mathrm{~km}$; or

c) Maximum of two organisations belong to the same operator as the one delivering*.

*Delivered organisations: only B2C or comply with conditions mentioned in a) and b)

d) Establishments where only 2 full-time equivalents are employed and deliveries do not meet the conditions mentioned in b) and c).

e) Establishments that handle and process meat

UK A butcher supplying retailers as well as final consumers from his own premises, may be exempt from approval as a cutting plant if the wholesale element of the business is 'marginal, localized and restricted' exemption

a) Marginal: supply of food of animal origin:

(a) up to a quarter of the business (25\%) (in terms of food); or

(b) in relation to: fresh or processed meat, (but not wild game meat) up to 2 tonnes a week, subject to the establishment having a genuine retail outlet supplying the final consumer with part of its production of meat;

b) Localised: supply of food of animal origin within the supplying establishment's own county plus the greater of either the neighbouring county or counties or $50 \mathrm{~km} / 30$ miles from the boundary of the supplying establishment's county;

c) Restricted: supply of food of animal origin is limited to certain types of products or establishments. In the meat sector, the restrictions are in relation to the amounts of meat supplied and the requirement for a 'genuine' retail outlet (see 'marginal' above).

EFSA_BIOHAZ. (2017). Scientific Opinion: Hazard analysis approaches for certain small retail establishments in view of the application of their food safety management systems. EFSA Journal, 15.

FASFC. (2015). Guide for autocontrol in the butchery-butcher shop (G-003-Version 2). http://www.favv.be/autocontrole-nl/gidsen/distributie/g003/, accessed on the 5th of July 2017.

Food_Standards_Scotland. (2013). ButcherSafe, Food Safety Assurance System. http://www.foodstandards.gov.scot/downloads/ButcherSafe Full PDF Manual with FSS logo.pdf, last accessed on the 20th of July 2018: TSO.

FSA. (2012). Safe food handling for butchers. https://acss.food.gov.uk/sites/default/files/butchershaccp.pdf, last accest on the 2nd of August 2018. 
Table 2: Comparison of the simplified hazard analysis approaches proposed by EFSA (EFSA BIOHAZ, 2017) with the current European hygiene legislation (EU Reg. 852/2004) and with the current guides to good practice used in Belgium and UK for butcher shops. In case in these documents, a difference was noticed with the EFSA opinionsimplified approach, this was highlighted in bold. The differences introduced by EFSA are highlighted in bold.

\begin{tabular}{|c|c|c|c|}
\hline Approach & 1 - Stage identification & 2 - Hazard identification & 3 - Hazard ranking \\
\hline $\begin{array}{l}\text { Simplified } \\
\text { Approach } \\
\text { approach } \\
\text { proposed in } \\
\text { EFSA } \\
\text { opinion } \\
\text { (EFSA_BIO } \\
\text { HAZ, 2017) }\end{array}$ & $\begin{array}{l}\text { - Flow diagrams to provide an } \\
\text { overview of the different stages. } \\
\text { - Detailed description of the activities } \\
\text { at each stage not required. } \\
\text { - General flow diagram is provided } \\
\text { for five target retail establishments. }\end{array}$ & $\begin{array}{l}\text { - The hazards are simply grouped as } \\
\text { 'biological', 'chemical', 'physical' or } \\
\text { 'allergen'. Sufficient to know the } \\
\text { most relevant 'groups of hazards' } \\
\text { - Structured questionnaire and } \\
\text { Ishikawa diagram provided to } \\
\text { identify activities contributing to an } \\
\text { increased/ decreased occurrence of } \\
\text { the hazard }\end{array}$ & $\begin{array}{l}\text { - Hazard ranking is not required for } \\
\text { the five-target small food retail } \\
\text { establishments. } \\
\text { - The hazards that might occur, most } \\
\text { efficiently controlled using PRPs. }\end{array}$ \\
\hline $\begin{array}{l}\text { Classical } \\
\text { Approach } \\
\text { approach } \\
\text { mentioned } \\
\text { in FFSA } \\
\text { opinion (EU } \\
\text { Reg. } \\
\text { 85/2/2004) }\end{array}$ & $\begin{array}{l}\text { - Flow diagrams summarising the } \\
\text { different stages are given. All } \\
\text { incoming streams and all outgoing } \\
\text { streams are included. } \\
\text { - Each stage is accompanied by a } \\
\text { short description of the activities and } \\
\text { A floor plan is required. }\end{array}$ & $\begin{array}{l}\text { - All relevant hazards (biological, } \\
\text { chemical, physical and allergens) } \\
\text { that may occur at each stage need } \\
\text { to be identified. } \\
\text { - Responsible person should know } \\
\text { detailed and hazard-specific } \\
\text { information. }\end{array}$ & $\begin{array}{l}\text { - Qualitative, semi-quantitative or } \\
\text { quantitative methods can be used to } \\
\text { rank the hazards. }\end{array}$ \\
\hline $\begin{array}{l}\text { Commission } \\
\text { Notice } \\
(2016 / C \\
278 / 01) \\
\text { without } \\
\text { flexibilities }\end{array}$ & $\begin{array}{l}\text { - Extensive flow diagrams including } \\
\text { all processes from receiving the raw } \\
\text { materials to placing the end product } \\
\text { on the market. } \\
\text { - Each stage is accompanied by a } \\
\text { description of the activities (incl. } \\
\text { delays during or between steps, etc.) }\end{array}$ & $\begin{array}{l}\text { - All relevant specific hazards } \\
\text { (biological, chemical, physical and } \\
\text { allergens) at each stage need to be } \\
\text { identified. } \\
\text { - Responsible person should know } \\
\text { detailed and hazard-specific } \\
\text { information. }\end{array}$ & $\begin{array}{l}\text { - Decision tree and/or semi- } \\
\text { quantitative risk evaluation methods } \\
\text { can be used to rank the hazards. }\end{array}$ \\
\hline $\begin{array}{l}\text { Commission } \\
\text { Notice } \\
(2016 / C \\
278 / 01) \\
\text { with } \\
\text { flexibilities }\end{array}$ & $\begin{array}{l}\text { - Flow diagram can be very simple. } \\
\text { - Similar products can be grouped. }\end{array}$ & $\begin{array}{l}\text { - Pre-determination of the hazards } \\
\text { by providing a general HACCP guide } \\
\text { or perform a general hazard analysis } \\
\text { is recommended. } \\
\text { - Detailed description of the nature } \\
\text { of the hazards is not required. }\end{array}$ & $\begin{array}{l}\text { - Simplified decision trees and/or } \\
\text { simplified semi-quantitative risk } \\
\text { evaluation methods can be used to } \\
\text { rank the hazards. }\end{array}$ \\
\hline $\begin{array}{l}\text { Guide BE } \\
\text { (FASFC, } \\
\text { 2015) }\end{array}$ & $\begin{array}{l}\text { - Flow diagrams are provided in the } \\
\text { guide for each type of product. } \\
\text { (Fresh meat, minced meat, meat } \\
\text { preparations etc.) } \\
\text { - No detailed description at each } \\
\text { stage required. }\end{array}$ & $\begin{array}{l}\text { - Hazard identification is done. } \\
\text { - Hazards are grouped as } \\
\text { 'biological', 'chemical', 'physical' or } \\
\text { 'allergen'. } \\
\text { - Activities contributing to an } \\
\text { increased/ decreased occurrence of } \\
\text { the hazard are also determined. }\end{array}$ & $\begin{array}{l}\text { - Hazard ranking is done for each } \\
\text { hazard. } \\
\text { - There are CCPs determined. } \\
\text { - Control measures are allocated to } \\
\text { the hazards. }\end{array}$ \\
\hline $\begin{array}{l}\text { Guide UK } \\
\text { ButcherSafe } \\
\text { (Food_Stan } \\
\text { dards_Scotl } \\
\text { and, 2013) }\end{array}$ & $\begin{array}{l}\text { - In the introduction, a general } \\
\text { simplified diagram is shown but does } \\
\text { not have all the process steps. } \\
\text { - Hazard analysis is based on the PRPs } \\
\text { (exclusive of : PRP } 8 \text { \& 12) and not on } \\
\text { the stages of the flow diagram. }\end{array}$ & $\begin{array}{l}\text { - For each PRP, hazards are } \\
\text { identified. } \\
\text { - Hazards are grouped as } \\
\text { 'microbiological', 'physical' and } \\
\text { 'chemical'. } \\
\text { - Short description is given, but not } \\
\text { detailed. Pathogens are called } \\
\text { harmful bacteria and not by their } \\
\text { species name. } \\
\text { - Allergens are handled separately. }\end{array}$ & $\begin{array}{l}\text { - No systematic hazard ranking step } \\
\text { involved. } \\
\text { - In the introduction, a definition is } \\
\text { given for CCPs and these are defined } \\
\text { as controls critical for food safety. } \\
\text { - The house rules (PRPs) are } \\
\text { considered as critical controls, which } \\
\text { should be accompanied by control } \\
\text { measures, monitoring activities, } \\
\text { corrective actions and record keeping. }\end{array}$ \\
\hline
\end{tabular}

Formatted: Font: Bold

Formatted: Font: Bold 
Table 2: Comparison of the simplified hazard analysis approaches proposed by EFSA (EFSA BIOHAZ, 2017) with the current European hygiene legislation (EU Reg. 852/2004) and with the current guides to good practice used in Belgium and UK for butcher shops. In case in these documents, a difference was noticed with the EFSA opinionsimplified approach, this was highlighted in bold. The differences introduced by EFSA are highlighted in bold.

\begin{tabular}{|c|c|c|}
\hline $\begin{array}{l}\text { Gyide UK } \\
\text { Safe Food } \\
\text { Halndling for } \\
\text { Buttchers } \\
\text { (F\$A, 2012) }\end{array}$ & $\begin{array}{l}\text { - All possible steps in butchery } \\
\text { operations are mentioned. The } \\
\text { butchers have to tick the box for the } \\
\text { applicable steps. }\end{array}$ & $\begin{array}{l}\text { - Microbiological hazards are } \\
\text { identified at each step. } \\
\text { - Chemical and physical } \\
\text { contamination and allergens are } \\
\text { handled separately. } \\
\text { - Hazards are not specified into } \\
\text { detail. Microbiological hazards are } \\
\text { just called food poisoning bacteria. }\end{array}$ \\
\hline
\end{tabular}

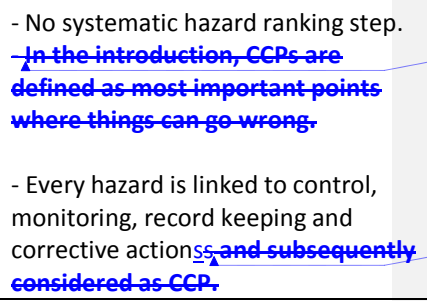

- No systematic hazard ranking step. In the introduction, CCPs-are defined as most important points where things can gowrong.

- Every hazard is linked to control monitoring, record keeping and corrective actionssandsusequently considered as CCP.

Formatted: Font: Bold

Formatted: Font: Bold

FASFC. (2015). Guide for autocontrol in the butchery-butcher shop (G-003-Version 2). http://www.favv.be/autocontrole-nl/gidsen/distributie/g003/, accessed on the 5th of July 2017.

Food_Standards_Scotland. (2013). ButcherSafe, Food Safety Assurance System. http://www.foodstandards.gov.scot/downloads/ButcherSafe -

Full PDF Manual with FSS logo.pdf, last accessed on the 20th of July 2018: TSO.

FSA. (2012). Safe food handling for butchers. https://acss.food.gov.uk/sites/default/files/butchershaccp.pdf, last accest on the 2nd of August 2018. 
Table 3: Comparison of requirements for Prerequisite program 'cleaning and disinfection' and 'temperature control of storage environment' described in the guides to good practice of Belgium and the UK with requirements proposed in EFSA opinion (EFSA_BIOHAZ, 2017). Changes (compared to requirements

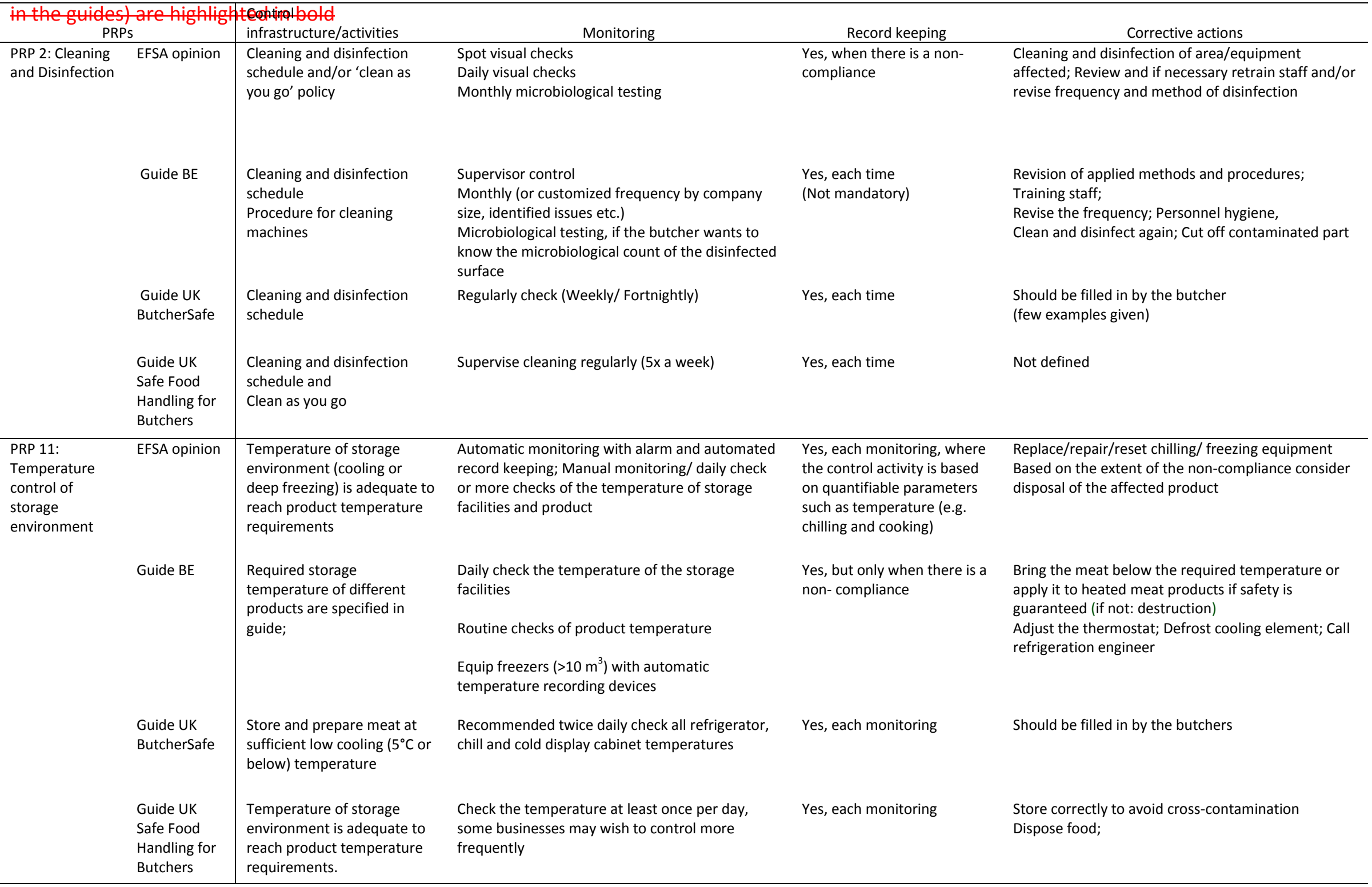


Figure 1: Web diagrams with the percentage of A:positive, negative and neutral opinions or B: negative opinions of the UK butchers ( $n=10$, left) and Belgian butchers $(n=10$, right) for the changes in PRP-prerequisite requirements introduced by the EFSA opinion (EFSA_BIOHAZ, 2017). Only requirements changed by the EFSA opinion are displayed, therefore less PRPs are indicated for the web of the UK butchers. $R$ stands for requirements related to record keeping, $M$ for monitoring requirements, PRP2(X) for monthly microbiological testing and PRP11(X) for Automatic monitoring with alarm and automated record keeping

EFSA_BIOHAZ. (2017). Scientific Opinion: Hazard analysis approaches for certain small retail establishments in view of the application of their food safety management systems. EFSA Journal, 15. 


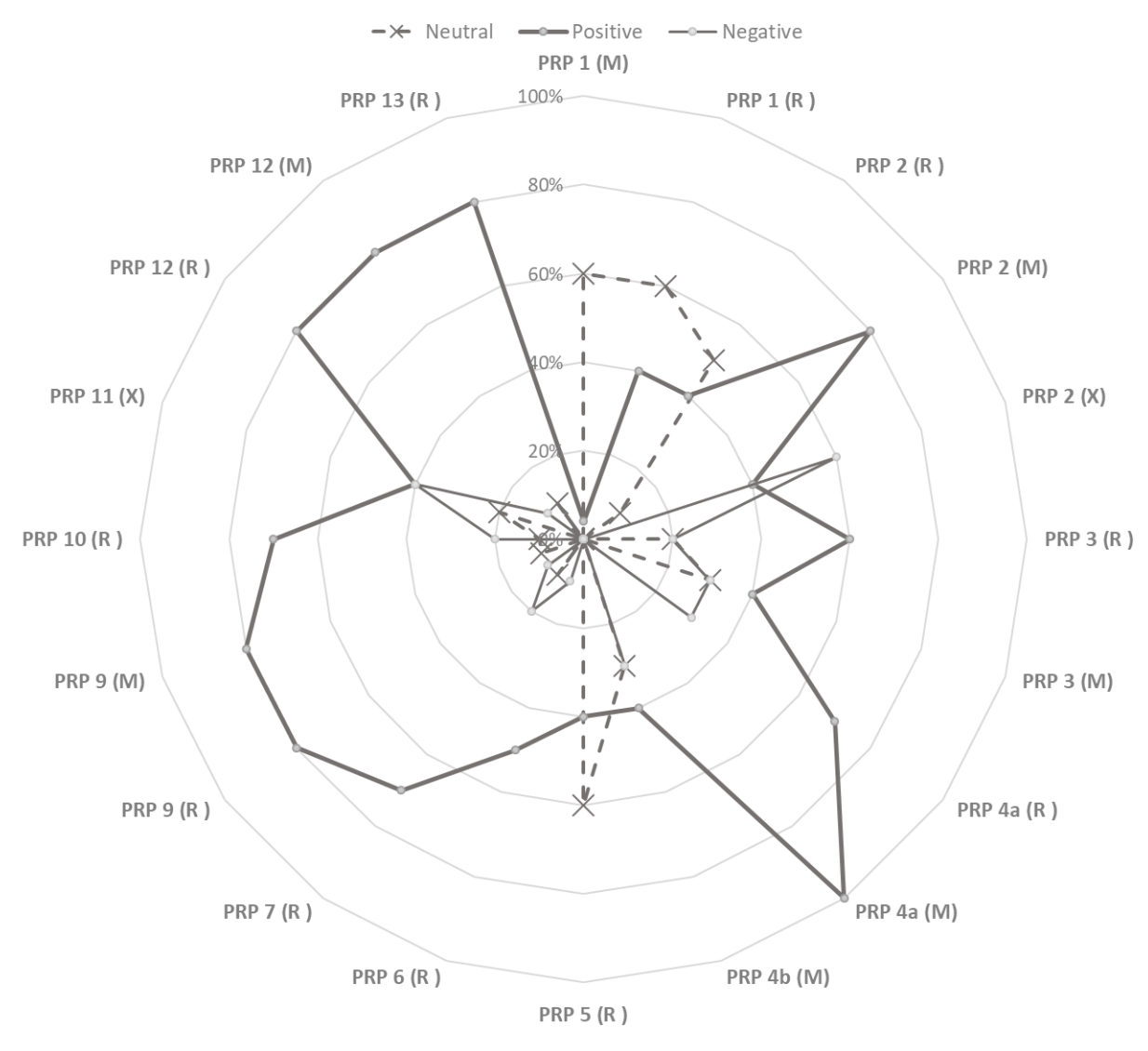

UK

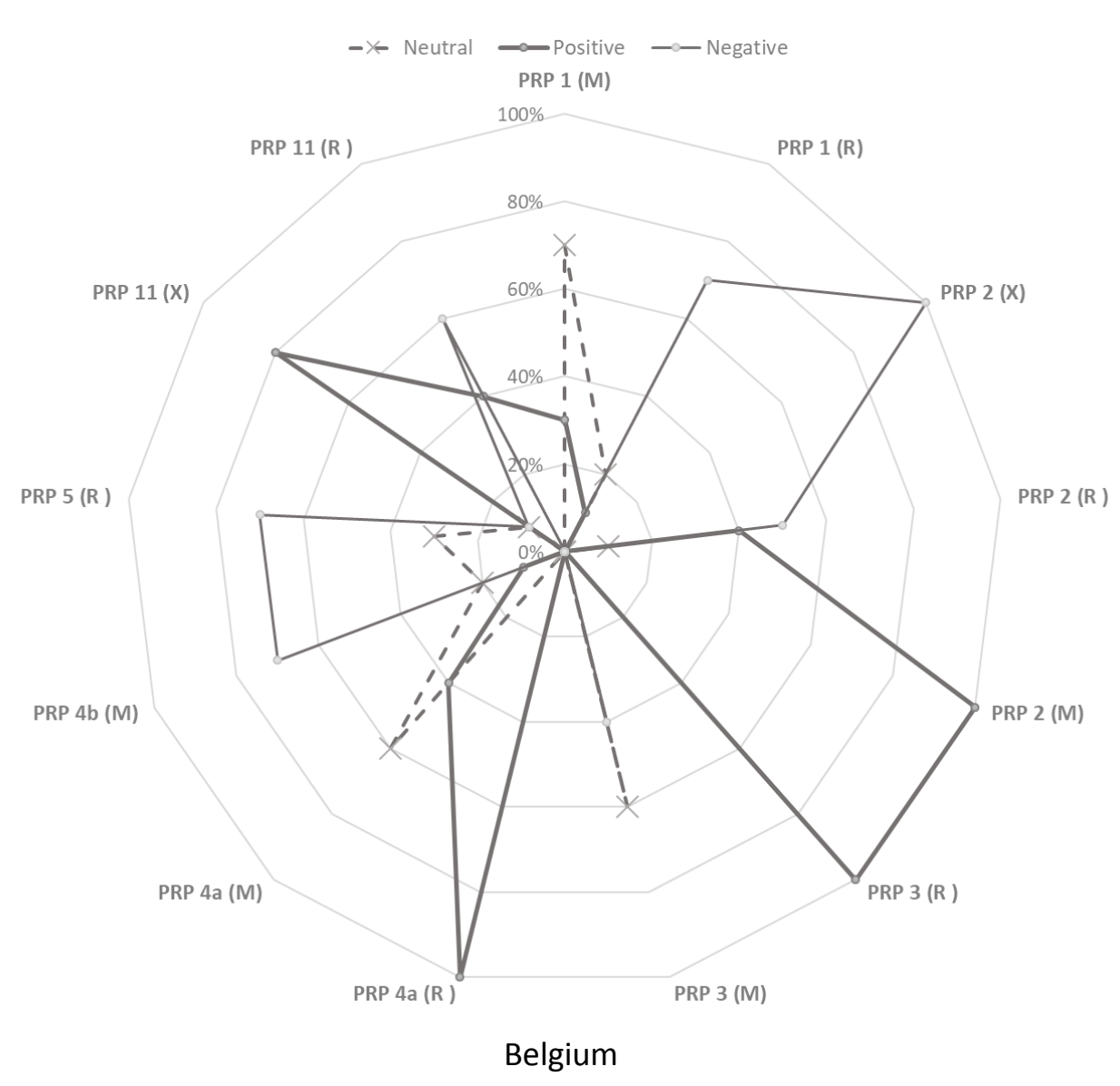

PRP 1: infrastructure, PRP 2: cleaning and disinfection, PRP 3: Pest control, PRP 4: Technical maintenance(a) and calibration(b), PRP 5: Physical and chemical contamination from production environment, PRP 6: Allergens, PRP 7: Waste management, PRP 8: Water and air (not included, as normal potable water is used), PRP 9: Personnel, PRP 10: Raw materials, RPR11: Temperature Control of Storage Environment, PRP 12: Working methodology, PRP 13: Product Information and Consumer Awareness 
- EFSA BIOHAZ panel proposed a simplified approach in food safety management

- The approach applies to small retail businesses such as small independent butcheries

- A critical review of the EFSA opinion is performed

- The opinion of butchers in Lancashire, UK and Flanders, Belgium is investigated

- The approach will advance butchers in a positive way and help harmonize flexibilities 


\section{Coaflict of Interest and Authonkip Cenformation Form}

Please check the following as apreopeiate:

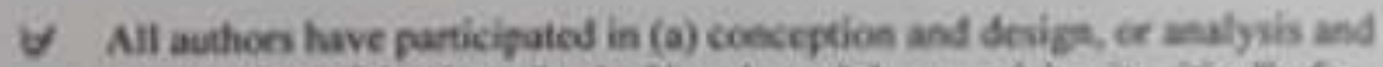
interptutation of the data; (b) drafting the article of revising it critically for important intellectas coetent; and (c) acproval of the final version.

p. Tis manuscript has nos bon sabenitted to, not is under review at, unceler joumat of ether pollishise wnue.

6. The athors have no affiliation with any organization with a direct or indirect finascial interest in the subjoct manter discussed in the manuscrips

- The following wuthors hyor antiliations with organizations with direct or indirect financial intecest in the subject macter disgrbod in the manuscript:

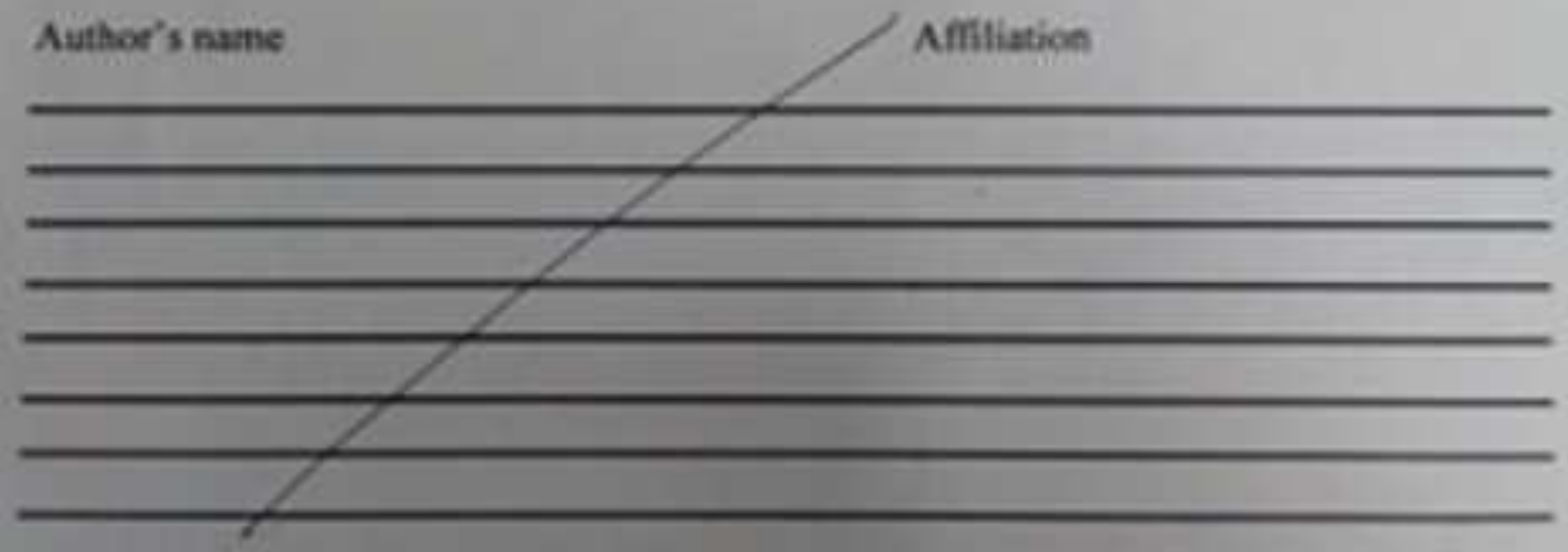

Be Boet Clin -910719

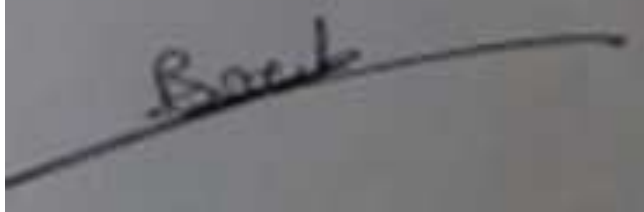

$L \in \mathbb{B} B+H$ JACXXUS 091071 halg

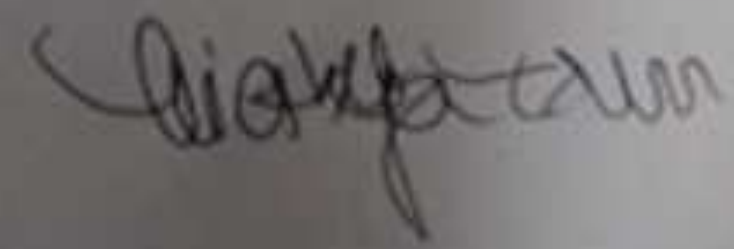




\section{Appendix A:}

\section{1)Questionnaire UK (Opinion about EFSA proposals)}

\section{General questions}

1. How many years of experience do you have?

2. How much employees do you have?

3. Are you using a guide for food safety management systems in butcher shops? Yes / No

(If yes) Which one are you using?

(If no) How do you get the right information concerning food safety management systems?

4. Are you a member of an organisation for butcheries which guides you through the implementation of the food safety management system? Yes / No.....

(If yes) Which organisation?

In order to help small butchers to implement a good-working food safety system, a simpler approach at European level is in the making. The European Commission has called on EFSA, their scientific advisory body, to elaborate this. Now, I will ask you some questions and try to determine to what extent this approach will help you, as a butcher, move forward.

\section{Conditions for flexibilities}

5. Do you supply only to the final consumer? Yes/ No.

(If no) Does the supply to other establishments exceed a quarter of your production? Yes/ No

(If yes) Does the supply to other establishments exceed 2 tonnes a week? Yes/ No

6. Are the supplied establishments localised (within 30 miles from the boundary of supplying establishment's county)? Yes/ No

If the conditions are not met, the interview ends. The butcher shop has to be eligible for the flexibilities.

7. Are you making meat products by yourself? Yes/ No

The simplified approach is only applicable for fresh meat, meat preparations and not for meat products. So, the current system must be followed for meat products.

Hazard analysis approach

8. Do you know what a HACCP-plan is? Yes/ No

9. Is the HACCP-plan premade in the guide? Yes/ No

10. Are the hazards ranked as CCP, CP and PRP? Yes/ No

11. Are the hazards determined at each step? Yes/ No

12. Are there CCPs determined (in the guide)? Yes/ No

13. Are the CCPs monitored and recorded? Yes/No

In the new approach, a simpler table is proposed to replace the current HACCP-plan. In this plan, no CCPS are included. The hazards should be controlled with hygiene practices. So, there is no distinction anymore between the practices in terms of CCPS, control points and hygiene practices. (Hazard ranking is removed.)

14. Would this help you?

Control activities

15. Do you have a temperature logger with alarm and automated record keeping? Yes/ No

Automatic monitoring with alarm and automatic record keeping is recommended.

16. Are you prepared to get one in your premise?

17. Do you fill in a delivering checklist each time? Yes/ No

EFSA proposes only recording when there is a non-compliance

18. Would these changes help you and ease your work?

19. Do you calibrate the thermometer and other measuring devices? Yes/No

20. In which frequency?....

21. Do you record the status of the calibration each time? Yes/NO

EFSA proposed to control the status of calibration more frequent, namely weakly or even daily (+o -). Record keeping by each control is required. Temperature is a main parameter which should be on point. That is the reason why the requirements of calibration are tightened.

22. What do you think about this proposal?

\section{Supervisor control}

23. Do you use a supervisor checklist? Yes/ No

24. In which frequency are you doing the supervisor check? Weekly/ Fortnightly/ Monthly/

25. Do you check each time the list and fill in the corrective actions taken? Yes/ No.......

26. Does the control the hygiene condition of the premise and equipment?

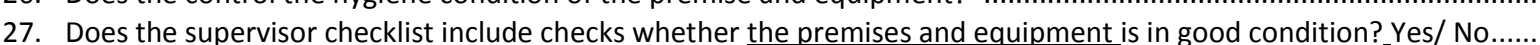
EFSA proposes a monthly visual check of the hygiene and condition infrastructure with record keeping only when there is a non-compliance. 
28. What do you think about this proposal?

29. Does the supervisor checklist include checks whether cleaning and disinfection has been carried out in the right way? Yes/ No

EFSA proposes a daily and spot control of the execution and a monthly microbiological testing.

30. Are you positive about this proposal?

31. Does the supervisor checklist include checks on pest control? Yes/ No

32. Do you work with a specialised firm for pests? Yes/ No

If yes, how frequent are they controlling?

EFSA proposed a weekly pest-control without recording the corrective actions when taken.

33. Would this change help you and ease your work?

34. How often is technical maintenance of the equipment done?

35. Do you keep documents to prove this? Yes/ No

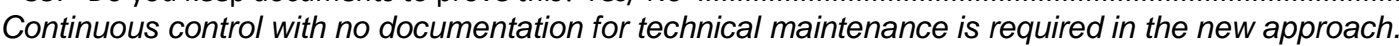

36. What do you think about this proposal?

37. Does the supervisor control list include checks on physical and chemical contamination is from environment? Yes/ No

EFSA propose check this during processing and monthly and only recording when remedial work is required.

38. What do you think about this proposal?

39. Do you have allergens in your assortment? Yes/ No

If yes; Does the supervisor checklist include checks on the requirements for allergens rules? Yes/ No

EFSA proposes to remove the record keeping requirement.

40. What do you think about this proposal?

41. Does the supervisor checklist include checks on waste control? Yes/ No

EFSA proposed to remove the record keeping requirement.

42. Would this change help you and ease your work?

43. Does the supervisor checklist include checks on personal hygiene of the staff including hand washing, clean clothes etc.? Yes/ No

EFSA proposes a daily visual check of the compliance on personal hygiene without record keeping.

44. What do you think about these proposals?

45. Does the supervisor checklist include checks on working method? Yes/ No

EFSA proposes a daily visual check of the compliance on working method of the staff without record keeping.

46. Would these changes help you and ease your work?

47. Does the supervisor checklist include checks on the awareness and the practices of the staff concerning product information (promote proper handling, storage and preparation by consumers, shelf life information and allergens)? Yes/ No

EFSA proposed to control the staff members whether they give sufficient information to the consumers without recording the corrective actions. This control should not be recorded.

48. What do you think of this proposal?. 


\section{2)Questionnaire Belgium (Opinion about EFSA proposals) \\ Algemene organisatie}

1. Hoeveel jaar ervaring heb je als slager?

2. Hoeveel medewerkers zijn er werkzaam in deze slagerij?

3. Zijn jullie aangesloten aan een bond of een organisatie die jullie begeleidt bij het uitvoeren van de hygiëneregels en het HACCP-plan? Ja / Neen

Zo ja, de welke?

4. Hoe blijft u op de hoogte van de veranderingen van de wetgeving van deze sector?

5. Maakt u gebruik van de autocontrolegids beenhouwerij-spekslagerij? Ja / Neen

Om kleine slagerijen zoals jullie verder te helpen bij het invoeren van een effectief voedselveiligheidssysteem wordt er op Europees niveau gewerkt aan een eenvoudigere aanpak. De Europese commissie heeft namelijk beroep gedaan op hun wetenschappelijk adviesorgaan EFSA om dit uit te werken. Nu ben ik verantwoordelijk om na te gaan in hoeverre deze aanpak jullie slagers zal vooruithelpen.

\section{Versoepelingen}

6. Wordt er enkel bediend aan de eindconsument of leveren jullie ook aan andere inrichtingen? Enkel B2C / Ook B2B $\rightarrow$ Indien vraag 6 "ook B2B"; Zijn de B2B activiteiten beperkt tot $30 \%$ van de omzet en binnen een straal van $80 \mathrm{~km}$ ? Ja / Neen

$\rightarrow$ Indien "Neen"; Zijn de B2B activiteiten beperkt tot het bevoorraden van maximaal 2 inrichtingen? Ja / Neen

(Inrichtingen leveren op hun beurt enkel aan de eindverbruiker ofwel max. 30\% van hun omzet binnen een straal van 80 $\mathrm{km}$ leveren aan andere inrichtingen en behoren tot dezelfde operator als deze die levert.)

$\rightarrow$ Indien "Neen"; Zijn er slechts twee voltijds equivalenten tewerkgesteld in de inrichting? Ja / Neen

7. Worden er vleesproducten, zoals worst en ham, gemaakt en verkocht? Ja / Neen

De aanpak van EFSA geldt enkel voor vers vlees, gehakt vlees en vleesbereidingen. Dus als de voorstellen van EFSA goedgekeurd zullen worden, zal u voor de verwerkte producten het huidige systeem moeten verderzetten.

\section{Gevarenanalyse (HACCP)}

8. Gebruikt $u$ de HACCP-plan in de gids of heeft $u$ er zelf een opgesteld?

9. Wordt er onderscheid gemaakt tussen de verschillende gevaren als CCP, PVA en GHP? Ja/ Neen

In het voorstel van EFSA wordt het HACCP-plan vervangen door een eenvoudiger tabel. Hierin worden weer de gevaren die in de slagerij kunnen optreden op voorhand gedefinieerd. Er wordt geen onderscheid meer gemaakt tussen CCP PVA en GHP. Alle gevaren worden beheerst m.b.v. goede praktijken.

10. Hoe zal u deze verandering ervaren?

BVP - Infrastructuur (gebouw en uitrusting)

11. Hoeveel keer per maand wordt er gecontroleerd op de orde en netheid van de inrichting en de uitrusting?

12. Wordt er daarbij telkens een controlelijst ingevuld? Ja / Neen

EFSA stelt voor om maandelijks een controle te houden en de controlelijst enkel in te vullen bij verbeteringsmaatregelen. Dus de registraties worden beperkt.

13. Zal dit u verder helpen?

BVP - Reiniging en ontsmetting

14. Hoeveel keer per maand wordt er gecontroleerd op de reiniging en ontsmetting van de omgeving en de uitrusting?

15. Wordt er daarbij telkens een controlelijst ingevuld? Ja / Neen

EFSA stelt voor om de controlelijst enkel in te vullen bij niet-naleving en deze controle dagelijks en steekproefsgewijs uit te voeren.

16. Hoe zal u deze verandering ervaren?

EFSA heeft voorgesteld om maandelijks microbiologische testen uit te voeren om de efficiëntie van de reiniging en ontsmetting na te gaan.

17. Staat u hier positief tegenover?

BVP - Ongediertebestrijding

18. Met welke frequentie controleert $u$ op ongedierte?

19. Wordt er een controlelijst ingevuld bij het nemen van correctieve acties? Ja/ Neen

Voor ongediertebestrijding raadt EFSA een wekelijkse controle zonder registratie. Dus geen controlelijst meer.

20. Zal deze verandering u verder helpen?

BVP - Technisch onderhoud en ijking

21. Worden alle toestellen (o.a. thermometer, weegschaal, MAP-verpakkingstoestel etc.) minstens jaarlijks technisch onderhouden? Ja / Neen

22. Worden de correctieve acties van technisch onderhoud bijgehouden? Ja / Neen 
Wat betreft technisch onderhoud stelt men voor om continu/regelmatig te onderhouden zonder documentatie bij te houden.

23. Wat vindt u hiervan?

24. Is er een procedure om de thermometer te ijken? Ja / Neen

25. Met welke frequentie wordt de ijkingstatus van de thermometer gecontroleerd?

Bovendien heeft EFSA voorgesteld om de ijkingstatus meer te controleren, namelijk wekelijks of zelfs dagelijks.

26. Wat is uw mening hierover?....

BVP- Fysische en chemische contaminatie van de omgeving

EFSA stelt voor om de acties die ondernomen worden indien er afwijkingen optreden i.v.m. fysische en chemische verontreiniging te noteren.

27. Wat is uw mening hierover?

BVP - Temperatuur controle van de opslagomgeving

28. Zijn de koelinstallaties e.d. voorzien van een automatische temperatuurregistratie-apparatuur? Ja/ Neen

29. Worden, bij het controleren van de temperatuur van de koelinstallaties, diepvriezers, het vlees e.d., de afwijkingen en de corrigerende acties geregistreerd op een controlelijst? Ja/ Neen

EFSA stelt voor om de temperatuur van de opslagfaciliteiten en producten telkens te registreren. Ook wordt er voorgesteld om te werken met een automatische temperatuurregistratie-apparatuur met alarm. Zo wordt continu de temperatuur van de opslagfaciliteiten optimaal gecontroleerd zonder dagelijkse inspanning.

30. Zal u deze verandering positief ervaren?

BVP - Productinformatie en consumentenbewustzijn

31. Wordt de nodige informatie over producten i.v.m. correct opslag, bereiding, houdbaarheid en allergenen mondeling overgebracht aan de consument? Ja / Neen

EFSA stelt voor om routinecontroles te houden om na te gaan of informatie mondeling of op de verpakking correct wordt overgebracht aan de klant. Deze informatie betreft correct verwerken, opslaan, bereiden, houdbaarheidsdatum en allergenen. Registratie is hierbij niet vereist.

32. Bent u mee met deze verandering? 